\title{
Play and Hysteria in Theatre Silviu Purcarete's Danaids
}

\author{
Adriana Titieni ${ }^{1}$, PhD, \\ University of Bucharest
}

doi: 10.19044/esj.2017.v13n18p9 URL:http://dx.doi.org/10.19044/esj.2017.v13n18p9

\begin{abstract}
The following article proposes a case study of Eschil's character, Hypermnestra from The Danaids trilogy. In the artistic process, all performances strike high notes of human sensitivity that only an unbalanced psychic can reach. The psychosis and the hysteria may constitute a model for the exaltation of the theatrical performance, without altering art's mimetic character.
\end{abstract}

Keywords: Eschil, The Danaids, Hypermnestra, antic theatre, hysteria in art.

\section{Introduction}

\section{Preface}

Between the many components of acting there is a hybrid zone in which exuberance and hysteria often meet. The dramatic action requests that type of contagious energy that is known to electrify the auditorium, attracting the beholder, determining him to participate, for a performance where the receptor is not a part of the game remains a simple artificial appearance. The art of acting means imparting and pure enthusiasm.

On the other hand, contagious happiness, hilarity or unhappiness projected in the other person can generate clinical states, mass psychosis for example or even the unleashing of narcissistic personalities that can reach collective hysteria, sometimes degenerating in behavior that is touched by psychical diseases (even sociopathic disorder). We will not approach the labile state in which the actor's mimicry meets various ludic derangements. In this article we are only interested in a few forms of achieving dramatic hysteria in the theatre performance. Our endeavor is based on building a role in The Danaids (1995), a performance directed by Silviu Purcărete at the

\footnotetext{
${ }^{1}$ Adriana Titieni is a film and theatre actress, Radio \&TV producer, associated professor to the University of Bucharest.

Roles: Hypermnestra in The Danaids (directed by Silviu Purcărete), Anetta in

Youth Without Youth (directed by Fr. Coppola)
} 
National Theatre in Craiova, co-produced with the Avignon, Wien and Amsterdam Festivals.

Presented in many places around the world, like Brazil, Great Britain, Wien or New York, The Danaids performance claimed unanimous interest, becoming the Romanian theatre phenomenon that received the most reviews, amongst other case studies we can refer to Les Danaïds, histoire d' un spectacle by Marina Constantinescu (1996).

Purcărete's mega-performance starts from the antic texts, The Danaids, The Priestesses and The Egyptian tragedies by Eschil, developing a grandiose vision in which the conflict is kept by the hysteria theme.

I played two roles in this performance and they represent the base for this present study. In the first part of the performance I played Hypermnestra continued symbolically in the second part by Amymone whom Poseidon saves from the 50 fauns that were chasing her.

Both serve the purpose that Silviu Purcărete envisioned which is to fuel the general hysteria through an opponent attitude. Both Hypermnestra and Amymone are characters that put a stop to the general impetuosity. "The marriage of Lynceus and Hypermnestra is based on mutual desire and affection. That is the affirmation with which The Danaid trilogy may well have ended, and it would not be unfitting if at its end those same Argive spearmen became the Danaids' new bridegrooms". (Sommerstein: 2010, p. 1017)

Hypermnestra is a Danaid who refuses to murder her husband, while Amymone gets lost in the night of the massacre, also failing to accomplish her mission of murdering her husband. In the story's diegesis, the Danaids, the 50 daughters of Danaos, the king of Argos, appear as untamed creatures, embodiments of insurgence manifested through hysteria and cruelty. The existence of a contrary element only accentuates the group's general disposition.

In constructing the role I started from a few general notes about dramatic exaltation and its sources.

\section{The labile psychology in the literary realism Psychosis}

The realistic dramatic literature marks the beginning of the modern era bringing the principle of veridical representation. And amongst the elements of artistic authenticity, the social component was defining. The main characters are ordinary people, fixed in easily recognizable human categories. There was also a vivid concern for the larger social frame and presenting it without any trace of idealization. The same path is followed in creating characters with a psychological trail observed in detail, applying popular psychological theories that led to a distinct sector in the end, dedicated to psychological investigation 
literature. From the end of the XIX century dramaturgy up to the end of the XX century, the character with complex psychology was in the spotlight.

Especially the psychoanalytical school at the end of the XIX century brought to the attention of literature subjects that triggered a definite interest.

Psychology treaties present psychosis as a major psychical affection of endogen nature that greatly disturbs the person's psychological life in regard to the way he/she reports to himself/herself and the world around. The subject's personality is profoundly altered; the conscience is affected, as well as the emotional and intellectual capacity that leads to the destruction of the person's behavior and social adaptability. Unlike the neurotic, the psychotic subject doesn't have the conscience of his disease. The notion correlates with that of alienation. The manner in which the person reports to himself, others and the world become amiss. It becomes impossible for the subject to establish an adequate relationship with the environment. The psychotic's universe looses touch with reality; his perspectives become deformed because of hallucinations. The most frequent clinically defined psychoses are maniac depression and paranoia. (apud V. Dem. Zamfirescu: 2007, pp. 71-82)

Literature, especially literature written in Ibsen realism, joggled with these notions preferring lunatic types of characters, marked by existential unhappiness, exaggerated up to the point in which clinical manifestations occur. The desire and the preoccupation for it are at the center of an unbalanced character. Emmanuel Lévinas defines it as aspiration converted to necessity: "In need I can bite off reality and be satisfied assimilating Another. In Desire there is no biting from the being, no satisfaction, but only the future without landmarks." (Lévinas: 1999, p.96). Any type of psychical unbalance has as starting point the desperation of the being that struggles to enter a relationship with someone willing or forced to offer otherness. Here more then anywhere else, in theatre, the human relationships are reduced to the basic gestures, put under the magnifying glass, thus bringing to the surface the senses of otherness or as Jung said that "common approach of people, produced by affine elements or the mechanisms of a community that have as effect a psychical intimacy connected to the instinctual sphere of human love." (Jung: 1999, I, p. 72). A character such as Blanche DuBois from A street cart named desire by Tennessee Williams has something from the psychotics' manifestation, although the roots of this behavior are nurtured by the desire of a harmonious affair. Starting from the first scene in which she is meeting her sister, Blanche shows her lack of confidence in herself which alters the way she reports to herself: "Now let me look at you. But don't you look at me. Stella, no, no, no, not yet. Not until I take a bath and rest! And turn that light off! Turn it off! I don't want to be looked at in this cruel light." (Contemporary American Theatre: 1967). This type of manifestation, completed by the 
author's descriptions, leads us to believe that the resemblance to the night butterfly is not accidental.

On the other hand, Masha, from A.P. Chekov's "The Seagull", is a case of depression, starting from self-blaming. She's wearing black clothes because she's unhappy. In psychoanalysis, mourning denotes a psychic process that allows the subject to give up an object he has lost. Throughout this process, the subject detaches itself, internalizing the loss. The death of a dear one brings a painful labor of internalization. The unfulfilled love for Costea makes Masha choose mourning as a form of self-punishment. The relationship of the subject with himself and the world suffers drastically. The oscillation of the character between melancholy and anger, between abandonment and the violence she wants to punish herself with places Masha in the maniacdepressive psychotic category.

Equally interesting are the hierarchical manifestations that can be found in modern dramatic literature. Derived from the Greek hystera, which means matrix, uterus, the term hysteria refers to a neurosis characterized by various clinical pictures. Its originality resides in the following: unconscious psychological conflicts are expressed theatrically and in the form of symbols, by paroxysmal bodily symptoms (epileptic seizures or seizures) or lasting ones (paralysis, contractions, blindness).

The two major forms of hysteria theorized by Sigmund Freud are hysteria of anxiety, the central symptom of which is phobia, and hysteria of conversion, expressed by repressed sexual representations. (Freud: 2010, pp.365 et seq.) In the Freudian conception, hysteria is a devastating way, with roots in primary narcissism, and at the same time it is also a type of manifestation of the rejected sexuality. The manifestations of the disease are diverse; Most of the times, there are features such as theatricality or the intensity of emotional expression and all that they imply, to the most complex type of literature: bovarism. Researched as narcissistic neurosis, Bovaricity combines melancholic expression and hysterical background, offering an important array of manifestations, from the adventurousness of the adventurer to the sickness of sadness and suicide.

In dramatic literature, since antiquity, there have been many characters that may have been said to have hysterical manifestations, and among these, I believe Martha, from Who is afraid of Virginia Woolf? fits best in the hysterical neurotic class. From the very first scene, we find a description of a possible form of hysterical manifestation made by George, her husband: "What else would you like to do? To be restless like you? To not have a moment of silence? To amaze everyone with my snicker? "(Theater ..., ibidem). Martha is a complex character with various passes from one emotion to another. Married to a university professor, six years younger than her, she is deeply unhappy. The difference between the characters of the two is perhaps 
one of the reasons for their misunderstandings. George is a sober, balanced psychological type, or, anyway, strives to keep within the limits of behavioral decency, and Martha is a woman with a pronounced psychological instability. Of course, this instability has its motives: one of them might be the unnatural closeness to her father, whom she considers a model of manhood and success in life. References to the father instance are numerous, and Martha's character is built on this obsession.

Fantasy and obsession are the ingredients of the game. George and Martha invoke a child; we find out that this imaginary child has long existed in the intimacy between the two and justifies us to believe that this simulated behavior was first induced by Martha. Exasperated by the whims, hoaxes and attacks of Martha, George decides to "kill" him. In front of their young guests, he announces the death of the imaginary child, which triggers Martha's fit, an attack of anger, of extreme violence, dramaturgically composed according to all the rules of a hysterical manifestation. However, she must also accept the reality. The invitation made to Martha to confess, acknowledge and assume reality, with all its facets, can be considered as a beginning to a "cure" for the psychological illness she suffers.

Chekhovian characters sometimes have a characterological basis in the area of hysteria as well, such as Constantin Gavrilovici Treplev from the "The Seagull". Complex, impossible to classify according to the classical, mysterious canons, the target of several blows of life, Treplev is one of the most engaging roles for an actor. Built on the Oedipus complex, as a failure who tragically lives intellectual and emotional unfulfillments, he commits suicide. The Oedipal complex appears here as an act of castration, because Treplev lacks the paternal opposition, that is, the rival who would have given him confirmation, dramatically replaced with the figure of a mother who deprives him of love. She leaves him at a very young age, remaining emotionally a child even at maturity. His manifestations of excessive excitement in front of his retrieved mother, excessive sensitivity, malady attachment to his mother, acquire the proportions of a hysteria in which the orphanage anxiety gradually turns into acute crisis.

\section{Modern psychology applied to the character of ancient tragedy}

Silviu Purcarete's play offered, as a generic line, the opportunity to create a mélange between the achievements of modern theater, concerned with anomalies and deviations of the psyche, and the philosophy of Antiquity. Read psychoanalytically, the ancient text bears the same metamorphosis that Oedipus, the character of Sofocle, had in Freud's psychoanalytic vision. Analyzed, all the stories of ancient tragedies offer human models of accuracy that allow an actor to create generic roles. 
Concerned with analyzing the pathos, Purcarete conceives the spectacle as a run of human feelings in front of a spectator who meditates from the very beginning on the mechanisms that can intensify a passion, especially an extreme and criminal one, like the one in The Danaids.

As in all the plays of Eschil, we find here a mystical conflict and an existential one, both of which inevitably lead to the Greek philosophy, in which fate is above people and above the Gods. The Danaids are intangible, rejecting any connection with men, even more so with their cousins, the sons of Aegyptus. They are the followers of Artemis, the ascetic, the guardian of virginity. By their choice, the Danaids defy Zeus, the god of fertilization. This conflict between the Gods and implicitly between their attributes or beliefs is specific to Eschil. And we have to mention that he never refers to a conflict of principles, but to ancient cults, adherents and mystical principles extremely valuable to the archaic world.

Furthermore, there is a script exclusively on hybris. The sons of Aegyptus committed a sacrilege, wanting to procreate with the Danaids not because they loved them, but because they intended to invalidate any claim that Danaos might have had on Egypt. However, if Danaos' daughters had accepted this abuse, everything would have ended there. Instead, their refusal, followed by a collective murder, accentuates the act of defiance of the Gods, which gives them the eternal punishment of carrying water in a bottomless vessel.

On this classic scheme are placed my two characters, in a symbolic relationship: Hypermnestra and Amymone. Both characters go beyond the general hysteria, the first to fall in love with her husband, and the second, wandering off on her wedding night. Both of them betray the cause of Danaos, but at the same time they escape a bloody ritual, saving themselves from eternal punishment. Both will be rewarded by Zeus, by giving birth to remarkable babies, by laying the foundations of noble nations, while their sisters will be condemned to give birth to people of no importance, establishing the nations that history will shatter.

On this typical drama for the Eschil's tragedy, Hypermnestra takes on, in Silviu Purcărete's play, the depths of the modern character. In the midst of a general hysteria, she is the element of normality, the model to which hysterics aspire. For in the crisis marked by multiple manifestations, in which narcissism takes forms of offensive display, there is actually a bitter misery, namely, not having reached a dreamed pattern. Or, Hypermnestra is precisely this ideal. She does not develop as a special character, for Purcarete has created a collective character. The Danaids are seen as a single character, a sort of entity in crisis, an incarnation of anger and protest. In the first phase, the Danaids are dominated by psychosis, experiencing intensely the disaster of the threat and the inability to remove the danger. It doesn't matter they are 
being threatened, but it matters that the threat is imminent. And this implacable destiny gets even more tragic accents as the desire of the sons of Aegyptus fades as part of fate. Marriage cannot be denied, cannot be removed. The Danaids are in the situation of Masha from "The Seagull", disoriented, without help and without the possibility of defending themselves. They are in mourning. Therefore, my character is part of the group, sharing the general terror. Yet through attitude, she also has hope unlike her sisters. She is always in a slight opposition, even if initially this is not visible.

After Danaos incites his daughters to kill, this formidable collective character grows in manifestations, acting hysterically, under the impulse of parental exhortation and duty towards their blood. Just at the beginning of the play, as a generic sentence, it is said that the harshest feelings are those maintained by kinship or love. But, the Danaids, as a compact group, act under the influence of their bloodline. Exaltation comes in ascendancy with the idea that the people of Danaos will lose all right over Egypt through a marriage that has the sole purpose of forfeiting this right. They're like Martha from Who's afraid of Virginia Woolf, improvising, hyperbolizing. The decision to kill their spouses represents symbolically the height of the crisis.

Therefore, Hypermnestra cannot act differently. She is part of the group and participates with the same exaltation to the plan of vengeance.

The moment of her individualization takes place before the slaughter, while she is waiting for Lynceus. It is the scene of Hypermnestra's dissent, who has already decided to procreate with Lynceus. In the scenic plan, the moment is marked by a monologue, the climax of my role. Although the moment is a preparation for the killing of the 50 grooms, I chose to build the monologue in the ingenious tone of the lover, trying to put emphasis on the antinomy the director had in mind. The Danaids "disappear," melting in the darkness of the scene, and Hypermnestra dominates the whole universe. She has decided to follow the laws of nature. The monologue is also a statement of love, but also an act doubled by the terror of others. Therefore, the dramatic construction had to preserve the sadness and suffering brought by death and also the joy of love. Imbued with murderous thoughts, Hypermnestra finds the way of life. She is that distant model that triggered hysteria. Her story illustrates what the Danaids had hoped for: love.

The scenic hysteria is based on contamination points. No screaming or vocal skidding gives the dimension of a hysterical psychosis, but its force to contaminate all the participants in the game, including the spectator.

Therefore hysteria as a disease uses theatricality, revealing the need of the man and the crossing. But these actions come from a psychological imbalance, a long series of suffering, frustration and repression.

Hysteria, artistically represented, finds a sublimation act, but has elements common to those of the disease. Any artistic act reaches that fierce 
boundary between normality and anomaly. The acting takes the imbalance, bringing it to the foreground, sometimes exaggerating its finest elements. But at the same time it brings symbolic elements capable of maintaining that area of missed aspiration, of the forbidden ideal. It is precisely this failure that lies at the root of a disease and any complex. Or, in the case of Purcarete's show, the general madness of some beings that pass in a short time from purity to killer becomes credible precisely through the Hypermnestra dissent.

Throughout the many rehearsals, following the feedback of the group, we chose only characterological elements that kept the group's tone. In the role study, the treatises and the experiments that are so useful in the lab do not matter, but rather the quality of their replies. If the replies from your partner do not touch you, it means your performance is poor. Therefore, the points of support of a monologue are regulated only by repetition and stage communication.

As a lost model of the Danaids, the Hypermnestra is a character that does not completely contrast with the group, reserving its exceptional role to strengthen the rule, preserving the accuracy of its actions, to set itself up as a model. Between the principles that are the foundation of the Hypermnestra, I would chose to name firstly its fleckless. She loses her lover and respect to the group, but preserves the essence of that humanity underlying any psychosis. The love of Hypermnestra is exactly the ideal that the Danaids missed when their cousins decided to make them brides against their will.

Amymone, the second character, is actually the symbolic hypostasis of Hypermnestra. She did not choose love; she lost herself, getting into the way of satyrs. Chased, threatened, she is saved by Poseidon, who will give her a noble son and noble kin. Amymone is an exception to the rule as well, but her escape is not voluntary. If Hypermnestra is the reason that bends in the midst of the most passionate of passions, Amymone is the instinct that acts under the impulse of self-preservation.

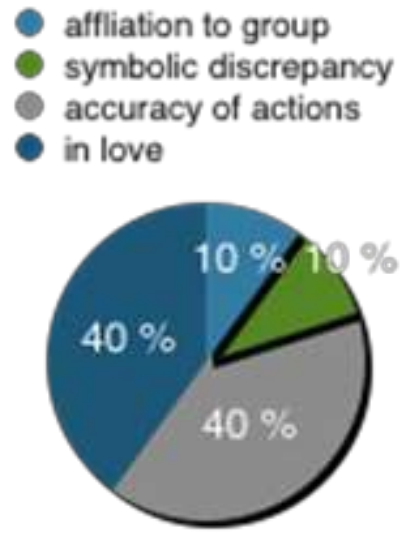




\section{Conclusion}

Silviu Purcărete's directorial perspective imposed an update of the theme and a psychological deepening of the character. As he once claimed, Eschil's trilogy "talks, in fact, about things that are familiar to us - exile, uprooting, fear of the other, identities and cultural differences. And exactly here have the demons of our times found a territory perfect for their games of peace and war."(Purcărete: 2015)

Therefore, for the studying of the role, I chose the construction of a character which, despite being in opposition to the collective character (The Danaids), maintains the antinomy at a moderate level, so that the character sets their role model at the base of an existential crisis. As essence of femininity, I consider Hypermnestra the ideal hidden in the soul of any Danaid.

\section{References:}

1. Constantinescu, Marina. 1996. Les Danaïdes, histoire d'un spectacle. Bucharest: Nemira Publishing House.

2. Sommerstein, Alan H.2010. Aeschylian Tragedy. London: Bloomsbury

3. Zamfirescu, V. Dem. 2007. Introduction to Freudian and Post Freudian psychoanalysis. Bucharest: Trei Publishing House.

4. Lévinas, Emmanuel.1999. Totality and infinite. Iași: Polirom Publishing House.

5. Jung, C. G. 1999. Symbols of metamorphosis. Vol. I-II, Bucharest: Teora Publishing House.

6. Freud, Sigmund. 2004. Introduction to psychoanalysis. Operas, vol.10. Bucharest: Trei Publishing House.

7. Contemporary American theater. 1967. Bucharest: EPLU.

8. Freud, Sigmund.2010. Introduction to psychoanalysis. Bucharest: Trei Publishing House.

9. Silviu Purcărete. 2015, 6 aprilie. Interview, HotNews. 